This item was submitted to Loughborough's Research Repository by the author.

Items in Figshare are protected by copyright, with all rights reserved, unless otherwise indicated.

\title{
'Just blokes doing blokes' stuff: Risk, gender and the collective performance of masculinity during the Eastern European stag tour weekend
}

\section{PLEASE CITE THE PUBLISHED VERSION}

http://dx.doi.org/10.1057/9781137341464

\section{PUBLISHER}

(c) Palgrave Macmillan

\section{VERSION}

AM (Accepted Manuscript)

\section{PUBLISHER STATEMENT}

This work is made available according to the conditions of the Creative Commons Attribution-NonCommercialNoDerivatives 4.0 International (CC BY-NC-ND 4.0) licence. Full details of this licence are available at: https://creativecommons.org/licenses/by-nc-nd/4.0/

\section{LICENCE}

CC BY-NC-ND 4.0

\section{REPOSITORY RECORD}

Thurnell-Read, Thomas P.. 2019. “just Blokes Doing Blokes' Stuff': Risk, Gender and the Collective Performance of Masculinity During the Eastern European Stag Tour Weekend". figshare. https://hdl.handle.net/2134/21448. 


\title{
4. 'Just Blokes doing Blokes' Stuff': Risk, Gender and the Collective Performance of Masculinity during the Eastern European Stag Tour Weekend
}

\author{
Thomas Thurnell-Read
}

The emergence in recent decades of the stag tour as a premarital ritual undertaken by large numbers of British men sheds new and at times vivid light on an array of connections linking notions of masculinity and travel. Starting with cities such as Amsterdam and Dublin in the 1990s, the stag tour 'phenomenon' soon spread East, with destinations in newly developing post-Soviet states of Central and Eastern Europe such as Prague, Riga and Budapest achieving a degree of notoriety for drunk and disorderly British men causing trouble fuelled by copious amounts of what was, for them, outrageously cheap beer and vodka. The streets of such cities where, according to the media, literally overrun with gangs of dishevelled and disrespectful male tourists, all eager to seek out fun, excitement and titillation at the expense of put upon locals; and yet, equally, such antics were and still are rarely greeted with more than a prosaic shrug and the dismissive assertion that, after all, 'boys will be boys'.

Such is the nature of the intimate links between travel and masculinity that while the images of half-dressed vomiting British men coming out of Eastern Europe were met with a large degree of contempt, such concerns were always tempered with a notably matter-of-fact resignation. Indeed, even stories of stays in foreign police cells, altercations with violent nightclub bouncers and tragic accidents rarely led to a sustained questioning of why, indeed, it should seem so normal for such men to seek out adventures abroad. Indeed, such risks evidently further entrenched the link between this form of travel and its ability to confirm masculine status on participants. Stag tourism is therefore an inescapably gendered phenomenon. The stag tour is held up, by the media in particular through programmes such as Stag Weekends: The Dirty Secrets (BBC, 2010) and Boozed Up Brits Abroad (Bravo TV, 2008), as an example of a bad masculinity which is brash, loutish and out of control. Such 
can be held to represent the worst excesses of a dominant masculinity which idealises the pursuit of beer, girls and 'good times' with friends whilst also, in many ways, being accepted as 'normal' or 'typical' and expected.

Through the behaviour and practices of British stag tourists in the tourism setting, the notions of risk and release, fun and excitement, friendship and sociability, are revealed through the specific constructions of masculinity in the actions and practices of stag tourism. Drawing on ethnographic fieldwork in Krakow, Poland, this chapter explores how the stag tour is established and sustained as a distinctly masculine tourist practice. The notion of risk and adventure is integral to this construction in fostering a particularly desired sense of playful release which typifies the stag experience. Further, the chapter identifies the ways in which specific perceptions and performances of masculinity and femininity interrelate within the stag tour context producing a complex dynamic of gendered interactions between stag tourists, local women and local men. Finally, in the concluding discussion, it is suggested that the masculinity displayed by stag tourists makes use of an easy slippage between a long-held serious, tough, adventurous, manliness associated with travel and a more ironic, playful, leisured masculinity.

\section{The Great Escape: For Men Only}

The implicitly gendered nature of international tourism has been addressed within the literature on several, but seemingly too few, occasions (Enloe, 1989; Kinnaird and Hall, 1994; Swain, 1995; Sinclair, 1997; Pritchard et al., 2007). Enloe (1989), for example, provided an early seminal analysis by outlining how the very idea of tourism is often founded on normative notions which associate men and masculinity with adventure and exploration and women with safety and domesticity. Further still, Pritchard and Morgan (2000) argue that the tourist gaze, as first coined by John Urry (1990), is invariably that of the privileged and 
heterosexual male, while Edensor and Kothari (1994: 185) have demonstrated how many tourist sites are deeply masculinised and privilege masculine forms of engagement with tourism.

The value here is to acknowledge that gender pervades all levels of the tourism industry and of tourist practice. As such, Kinnaird and Hall (1994: 2) have called for a framework 'based on the recognition that tourism processes are gendered in their construction, presentation and consumption, and the form of this gendering is configured in different and diverse ways which are both temporally and spatially specific'. We may, therefore, go as far as to say that tourism 'is built of human relations, and thus impacts and is impacted by global and local gender relations' (Swain, 1995: 247). This position firstly recognises that in being made up of gendered human relations tourism is itself inescapably gendered and that, secondly, the highly gendered nature of tourism is both shaped by and has the power to shape gender relationships and roles at all levels.

It would appear, then, that in order to understand a phenomenon such as stag tourism which is so readily interpreted as being a typical and overtly 'masculine' activity we must consider the various ways the stag tour experience is reliant upon notions of gender and upon heavily gendered interactions within the tourist setting. Stag tourism is both a characteristically masculine pursuit but also dependent on the gendered and sexualised relationship with the women who work in the pubs, bars, clubs and strip clubs which play host to them. Most notably, studies of sex tourism have highlighted the sexualisation of women by male tourists which is based upon strikingly unequal power relations (Cohen, 1982; Enloe, 1989; Sanchez Taylor, 2000). In a study of the sexualised promotion of the Thai resort of Phuket, Hobbs et al. (2011) observe that industry advertising, media depictions and, increasingly, the internet all draw heavily on gender stereotypes which allow the resort to be 'portrayed as a patriarchal world where a man believes he can live his fantasy of being the 
perfect hegemonic male' and where 'men are encouraged to pursue the traits of masculine hegemony’ (Hobbs et al., 2011: 99). Similarly, in her research on cross-border sex tourism between the USA and Mexico, Katsulis (2010; and this volume) suggests that the confluence of gendered, classed and racialised subjectivities present in destinations such as Tijuana allow American men to 'live like kings' and 'experience a form of masculinised sexuality that might be inaccessible to them in their home culture' (Katsulis, 2010: 222). As such, the invariably male tourist is economically in a position of power over the female host and, further, this economic power is bound up with certain gendered, and frequently racialised, notions of superiority.

What emerges out of such literature is a picture of how tourist spaces and practices, for many men, offer the opportunity to work at and towards a particular performance of masculinity. Linda Malam (2004) notes, in her work on beach resorts in Thailand, that tourism spaces offer intriguing settings in which the gendered identity of both tourists and the workers who serve them may be worked upon and reconfigured. Likewise, a trend in studies of masculinity more generally has been to stress the situational and contextual nature of men's masculine performativity. Specifically, as a now substantial body of literature has identified, it is the field of leisure and the night-time economy which has received notable attention as a site in which masculinity is frequently enacted (Campbell, 2000; Blackshaw, 2003; Nayak, 2003). As this chapter identifies, the stag tour provides a context in which tourist experiences are demanded and provided according to a heavily masculinised 'script' which draws notably the supposed association between masculinity, adventure and dominance. 


\section{Methods and Context}

This chapter will explore the links between the social construction of masculinity and tourism through discussing findings from an ethnographic study conducted in the Polish city of Krakow between 2007 and 2008. Participant observation was conducted with eight separate stag tour groups from various areas of Britain and ranging in size from eight to nineteen members and aged between the early twenties and mid-thirties. Access to these groups was initially secured with the assistance of a local tour company who provide mixed packages of accommodation, activities and guided tours to stag tour groups. Further contact was made with groups in the field. In all cases the researcher made his role as a sociologist researching stag tourism in Poland clear and sought informed consent from participants. The author accompanied groups to bars, nightclubs and restaurants and, during the day time, also spent time with groups as they partook in activities such as go-carting and sightseeing in the city's

Old Town. Time was also spent observing the city’s nightlife in a non-participator role and formal and informal interviews with tour company workers and local residents were conducted. Additionally, diverse textual and visual content was collected including media reports from Polish and British print and broadcast media, promotional materials from stag tour company websites and internet forums and review websites. During research, the author drank alcohol with tour participants though, for a number of reasons most notably concerns for recall when taking ethnographic field notes, sought to manage intake to prevent too great a level of intoxication (for in-depth methodological reflections see Thurnell-Read, 2011a).

\section{Gendering the Stag Tour}

Pursuing a few of the websites belonging to the numerous stag tour companies offering packages of accommodation, activities and tour guide services to predominantly British customers it becomes clear that the stag tour is geared towards a very narrow cache of 
typically 'male' pursuits. While this, in itself, comes as no surprise given such companies are catering solely for male customers, it is revealing in the range of stereotypical 'masculine' interests and traits which are deployed in constructing the stag tour. Popular activities offered by stag tour companies include motorsports such as go-cart racing, quad bike driving and even tank driving, firearms based activities such as paintball games and pistol and riffle shooting and food and drink events such as vodka tastings, brewery tours and 'medieval' style banquets of grilled meat washed down with jugs of beer. Such events are evidently informed by notions of masculinity as revolving around weaponry and warfare, competition, technical mastery of machines and indulgent consumption.

A further reflection of the gendering of the stag tour industry was found in the general pattern of marketing by such companies which focus on alcohol, bar and club-hopping and the overt use of images of Eastern European women as part of the branding of destination cities. A common and in some cases overwhelming feature of stag tour company sites, therefore, is the representation of Eastern European women as sexually appealing and available. The destinations chosen by stag tourists are themselves gendered in that there was an evident perception of Eastern European cities such as Krakow being 'male' destinations (Thurnell-Read, 2011b). As such, when asked about destination choices a characteristic response would emphasise the apparently self-explanatory, and deeply masculinised, nature of cities such as Krakow. One stag tourist, for example, matter-of-factly asserted: 'The beer is cheap and strong and the women are hot, what more can a bloke ask for?!'.

Amongst companies offering both stag and hen tours, for male and female customers respectively, it was common for websites to split between stag and hen areas, the assumed intention being both to direct potential customers to the relevant content but also to build a sense of gender segregated exclusivity. Thus, even in the planning stages the stag tour begins its symbolic construction as an exclusively male space. Interestingly, the stag tourist noted 
above, when asked about his fiancé's corresponding hen party, merely commented: 'Oh they're just going out in Leeds'. Here, the British city Leeds is held as a mundane and 'safe' feminine destination in contrast to the more adventurous, far-flung, masculine destination represented by the Eastern European city of Krakow. When stag tourists spoke of hen parties which did make foreign cities their destinations it was, indeed, far more common for more traditional beach orientated holiday resorts to be favoured. This is supported by reviewing tour company websites which revealed a noticeably East-West divide with stag destinations all predominantly in Central or Eastern Europe and popular hen destinations more focused on the Western European destinations lining the Spanish Mediterranean coast and Islands such as Mallorca (Andews, this volume). Frohlick (2010) has noted the tendency for women's bodies to be the subject of a political and moral discourse concerning safety and risk which, we must note, the bodies of male travellers rarely are. Such, it seems, is reflected in this tendency for 'safer' destinations to be seen as more appropriate for female hen parties while the 'danger' implicit in the stag tour weekend is left largely unchallenged.

Krakow as a stag tour destination is heavily sexualised; the women who come into contact with stag tourists through their work in the city's bars, restaurants and nightclubs, or merely through being present in the public spaces the stag tour groups also temporarily inhabit, are frequently subject of a sexualised gaze. Indeed, many have noted this use of the female body as commodity in the sale of tourist experiences to men. Sinclair (1997: 5), for example, observes that 'gendered and sexualised modes of behaviour and appearance are often demanded and supplied as part of tourism transactions'. Observations throughout fieldwork further support the assertion that the expectations of male tourists are frequently based on the assumption that the women of the countries they visit are 'more available and submissive than the women of their own countries' (Enloe, 1989: 36). With stag tourism, although this dynamic is most obvious in the commodification of female bodies in strip clubs, 
and in some instances escort agencies and brothels, with the majority of stag tourists their more mundane interactions with women in the tourist setting, that nonetheless replicate a strict female-male served-served binary, were evidently informed by the sense that gendered unequal power relations were an implicit part of the stag tour phenomenon.

\section{Risk and Adventure}

The 'myth' of the noble explorer is deeply engrained in the Western consciousness and, while a growing number of female travellers appear to be deploying such in their travel narratives, remains a typical male trope (Laing and Crouch, 2011). Recent research has identified some of the ways in which male tourists are seen to readily incorporate risky and dangerous behaviour into their experiences of travel and tourism (also see Lozanski, this volume). Thus, adventurous and physically demanding travel experiences are frequently central to the travel narratives of young male travellers (for example, see Noy, 2007). Likewise, research on young Danish tourists in coastal resorts in Bulgaria found that men reported higher levels of alcohol, tobacco and illicit drug use on holiday (Tutenges, 2012) and men were also found to be more likely to visit strip clubs and sex shows (Hesse and Tutenges, 2011).

The notion that a stag tour to a distant country is suitable for men whereas the female equivalent, the hen party, is far more commonly restricted to domestic cities in the UK within easier reach from the hometowns of participants therefore reflects a persistent gendering of travel along dichotomous lines. Home and away, risk and safety, are played against each other. The stag tour weekend is heavily reliant upon a narrative of risk and adventure. While, for some, the heavy drinking might mean daylight hours spent recuperating in hotel rooms, the evening and nights saw stag groups exploring the city's streets and bars. Throughout fieldwork stag groups would be keen to 'explore' the city, with many stag tour group members speaking of finding bars and clubs 'where the locals go to drink'. Interestingly, a 
further tendency was noted for many stag tourists to draw on analogies with warfare and sport to describe the trials and tribulations of the weekend. As such, a sizable stag group literally filling the dance floor of a nightclub have 'invaded the place', grazed knees from falling over during a drunken sprint across the Krakow Old Town market square become 'war wounds' and a stag is encouraged by his friends not to 'give in and be defeated' by a particularly agonising hangovers felt the next morning to which 'surrender is not an option!'. Such 'cross-fertilisation' between different fields of masculinity has been noted by both Spracklen (2013: 85) and Noy (2007) and reminds us that travel, war and competitive sports have a long history of supporting hegemonic ideals of masculinity as tough, independent and adventurous.

This desire to explore the city coupled with the disinhibiting nature of the stag tour gives rise to a range of potentially risky or dangerous situations. In recent years, numerous accidents have been reported by both Polish and British media. In June 2012, for example, the death of Graeme Hartis was widely reported in the British media after the former soldier dived from his hotel balcony into a Slovakian lake during his best friend's stag tour (Poonan, 2012). The British Foreign and Commonwealth Office (2005) issued a report in August 2005 featuring guidelines in an attempt to highlight the potential for harm and damage on overseas stag tours. In spite of this, ongoing news coverage continues to raise concerns about the strains placed on British consular services by stag tour groups in Eastern European cities (Sherman, 2006; Channel 4 News, 20 September 2007). Interestingly, Tutenges (2012) observes that the negative reputation of such destinations cultivated in the media in fact fosters interest among young male tourists drawn by the allure of a holiday environment where drunkenness, disinhibition and spontaneity are encouraged and accepted. Indeed, such negative portrayals of Eastern European cities ultimately prove counterproductive when so readily fed into narratives of masculine travel which valorise risk, danger and adventure. 
The notion of risk was evidently seen to be an integral element of the stag tour and a theme readily acknowledged by stag tour participants who held the excitement of 'causing mayhem' and 'getting messy' (similarly, see Treadwell in this volume). However, many participants also spoke favourably of engaging the services of a stag tour company who provided a tour guide as a means of ensuring that such dangers were to some extent mitigated. Indeed, stag tour guides worked tirelessly to ensure that stag tourists did not come to any harm by, for example, falling foul of local nightclub security staff, in their inebriated disorientation becoming detached from the group or, through their own drunken misadventure, injuring or otherwise harming themselves. However, stag tourists were, in many cases, not aware of how orchestrated the tour was. One attributes this to the astuteness of stag tour companies and their staff who recognise stag tourists desire for a sense of adventure but who would, in the vast majority of cases, never wish to spend a night in a foreign prison cell or hospital bed. Thus, tour companies worked to build up rapport with bar and club owners and would strategically manage the time and the duration of visits by stag groups on their guided bar crawls so as to take in many drinking venues yet to never outstay the group's welcome in one particular locations. The dangerous elements of the stag tour are, therefore, often finally balanced. Risk and adventure are knowingly cultivated yet stage managed by tour companies and tour guides and willingly consumed by stag tour participants.

\section{Performing Masculinity on the Stag Tour}

Within the physical setting of the Krakow old town centre, stag tourists deploy their bodies in specifically heterosexual and implicitly masculine ways. The male body of the stag tourists expresses its heterosexuality though performing an unruly masculinity which is drunk, unrestrained and frequently seen as 'out of control' (Thurnell-Read, 2011c). This sense of 
performance pervades the stag tour and, particularly, places a demand on the individual members of stag tour groups to act out a particular collectively defined performance of masculinity. This section will, therefore, explore the various ways which the collective performance of masculinity during the stag tour is constructed through placing various pressures on group members to align their gendered behaviour with that of the group. Indeed, many research participants spoke of being concerned prior to the trip about 'fitting in'.

Central to Connell’s (1987; 1995; Connell and Messerschmitt, 2005) conception of hegemonic masculinity is the notion of complicity where, both at a structural and an interpersonal level, the majority of men who might not achieve the hegemonic ideal of masculinity in any coherent form do, nonetheless, comply with and both directly and indirectly condone the dominant practices and actions. Stag tourism, then, provides an interesting case for exploring how such complicity is put into action in practice. The emphasis on sociability and the importance placed on mutual engagement in shared activities therefore ought to be seen as complicity in action. The sense of being 'up for a laugh' and of being willing to participate in the shared experiences endorsed by the group is both a means of complying with the situationally defined expression of masculinity (for a more detailed analysis of the nature of homosocial boding and friendship during the stag tour see ThurnellRead, 2012). However, what becomes apparent is that although the stag tour might appear to entail a sense of spontaneity and 'natural' masculine pursuits this does not, in fact, come without significant efforts made by group members and others in specific 'supporting roles'.

Prominent in this sense is the Best Man, chosen by the groom to be tasked with much of the planning of the stag tour weekend, from selecting destination, gathering deposits from participants and, most noticeably, orchestrating the events and activities during the weekend itself. More specifically, the Best Man might organise and distribute fancy dress costumes or matching 'team' shirts as well as hold the 'kitty' used to buy rounds of drinks in bars and 
clubs. The success of the Best Man, it often seemed, relied upon his ability to strategically manage the group and encourage a sense of joviality and playfulness. To this end, it was common for the Best Man to have spent considerable time before the weekend itself in devising often elaborate drinking games, the playing of which would unavoidably involve rapid consumption of alcohol by all group members. Likewise, the Best Man would invariably take the lead in initiating various challenges and tasks which the stag had to then carry out whilst being supplied with copious amounts of alcohol in the form of 'forfeits'.

A closer reading of the drinking games devised by stag tour groups adds further light to the gendered nature of the stag tour and, in particular, how a particular collective masculinity is constructed around an adventurous, boisterous, masculinity. For example, one stag was for the entirety of the weekend ordered to drink a shot of vodka, regardless of time or location whenever they mentioned either the bride or the wedding itself. In another group, each member of the group were encouraged to tip 'three fingers', a portion of each of their drinks, into a glass from which the stag would then drink. In both cases we can clearly see the implication of the game in terms of gender; in the former, the stag is punished for failure to distance himself from the perceived feminising effect of the looming marriage and, in the latter, the stag is bound to the male group through his act of drinking a portion of each participant's drink.

A further important actor in the stag tour weekend was, for those groups who chose to book an organised package from a tour company, the tour guide provided to oversee their time in the city. Inhabiting a similar facilitating role to the Best Man, the tour guide would also be involved in ensuring the smooth running of the weekend and, like the Best Man, with aligning the actual festivities with expectations. Tour guides would, for example, encourage quieter members of the group to drink a shot of vodka in order to 'get into the spirit' of the weekend. In one group, for example, the tour guide danced with the groom and several other 
members of the group on an otherwise empty dance floor. While this act is in itself unremarkable, the guide later explained in an interview that she would often dance with members of the group as she felt they expected to receive some interaction from women during the night out. It was therefore, in her words, her job to 'flirt a bit with them and to let them flirt a bit with me'.

One common theme raised by participants was the perceived threat of local men who were seen to express hostility to the presence of stag tourists in the city. A member of Phil's group, for example, responded to the perceived threat of local men in the club, by saying 'don't like the look of that big fucker, looks fucking nuts', and 'since we got here there's been a few places we think we're going to get our heads kicked in for sure, think they want to protect their women or something'. Such talk was common amongst stag groups as they made their way through the city, evidently aware of the potential for confrontation with local men. Stag tourists would talk of some local men as being threatening though their cropped ‘skin-head’ haircut, muscular physique and bodily comportment.

Groups would speak of Polish men, labelling their bodies in such a way as to locate them as being symbolic of a traditional masculinity based on strength and toughness. In contrast, the bodies of British stag tourists would be spoken of by the group in a way to draw lines of difference between them and local men; for example, pointing out that British men while not being strong and muscular are more ‘fun’ and up for having a laugh. Interestingly, not having to perform a tough and aggressive 'hard' masculinity was used by British men to draw a line of distinction between them and some of the Polish men they would at times come into contact with. Such talk serves to normalise the masculinity of British stag tourists as acceptable whilst relegating the perceived tough pose of some Polish men to a position of subordination as masculine 'Other'. In this light, the interaction between stag tourists and 
others in the tourist setting illustrates how gender embodiment is constructed through the interface between various competing gendered bodily subjects within the tourist setting.

\section{Discussion and Conclusion}

This chapter has sought to show how the stag tour made by groups of British men to Eastern European cities such as Krakow is informed by dominant codes of masculinity based on notions of risk and adventure and constituted in relation to the gendered interaction that takes place within the group and between the group and others such as tour guides or groups of local men. Within stag tour groups there is a high level of complicity which, it is argued, is analogous of a wider sense of complicity with hegemonic masculinity as identified in the work of Connell (1987; 1995; Connell and Messerschmidt, 2005). Further still, in various ways this performance of masculinity is shown to be relational and, as such, enacted in reference to the gender of others such as, notably, local women and men and other groups of stag tourists. Such concurs with the assertion made by Frohlick (2013) concerning the importance of observing the complexity of gendered interactions in tourist settings where the respective femininities and masculinities of female and male tourists and local women and men, both working in and not working in the tourist industry, interrelate as part of a wider power dynamic built upon gender, class, ethnicity and sexuality.

However, a closer reading of these discourses relating to masculinity and travel reveals some notable tensions. One aspect worth further discussion is how the depiction of masculinity oscillates between the serious and the mundane, between the adventurous risk taking explorer and the infantilised and self-deprecating bloke ‘up for a laugh' but never to be taken too seriously. While much of the performance of masculinity within the stag tour setting is overt, and certainly, at times, spectacular, it is noteworthy that much of the observed 'doing' of masculinity was tinged with irony. Examples of this include knowing 
references to gun shooting as a 'manly' activity or reference by the group to themselves as ‘just a bunch of pissed-up blokes' or, as the title of this chapter suggests, 'just blokes doing blokes' stuff'. Such comments, particularly the latter, can be read as attempts to underplay the actions of the group in their conformity to dominate masculine stereotypes. Many authors have noted the importance of irony in allowing men to enact highly gendered behaviour whilst distancing themselves from reproach or accusations of sexism or insensitivity (Whelehan, 2000; Benwell, 2003, 2004; Korobov, 2005, 2009). The influential concepts of fun, frivolity and playfulness which pervade the tourist setting are particularly well suited to the ironic assertion of masculinity.

Many participants appeared to feel that they can 'play the game' and retain masculine spaces for homosocial bonding while not allowing those times to encroach on their relationships in the work and family sphere. Indeed, the much used phrase 'what happens on tour stays on tour' deployed with striking frequency by stag tour participants appears to indicate, on several levels, the wish to compartmentalise the stag tour weekend as its own arena, behaviour within which is exclusive of how participants might act at 'home'. Both Tony Jefferson’s (2002) notion of ‘context-specific hegemonic strategies’ and Tony Coles’ (2009) work on 'fields' of masculinity shed light on this. Clearly the stag tourists are largely knowing and aware of their enactment of hegemonic masculinity, yet it is the physical and social context which makes this so readily possible. Indeed, on numerous occasions individuals, clearly aware of the negative reputation of stag tourists, expressed how their behaviour during the stag tour bore very little similarity to their behaviour at home and in other situations.

Thus, it seems that the tourist setting and, indeed, the very notion of tourism as based on adventure and risk taking provides a setting conducive to the enactment of dominant codes of masculinity. Stag tourism is experienced within a specific social space and time, identified, 
through an ongoing process, as a spatial-temporal location for the enactment of a certain form of playful masculinity which, at times, transgresses various aspects of social propriety. In this sense, it has been noted that sexualised environments, such as strip clubs and gentlemen's clubs, where men can act out behaviour for which they might be more readily chastised or less easily achieved in more prosaic settings (Donlon and Agrusa, 2003). The tourist setting of stag tourism provides the men who partake in stag tours with a space and time for engaging in behaviour explicitly coded as masculine.

Much of the bombast of the stag tour is notable for its ostentation, and certainly draws attention and much scorn from the media, academics and the general public alike, but also, we must conclude, offers participants a readily available and in many senses reassuring view of masculinity. The stag tour is socially constructed to offer a space for the unproblematic assertion and at times ironic enactment of normative masculinity and, thus, provides a degree of certainty. In Blackshaw's (2003) study, the night-time economy offered his participant group of men a refuge from the wider world where work place and home life roles were rapidly changing. In this it is more aligned with conceptions of a 'crisis' which sees, not a wholesale erosion of masculine identity, but rather a shift to assertions of masculinity which are more compartmentalised, working within the flexibility which is evident in the identity constructions of many men.

The stag tour weekend offers an insight into wider notions of how masculinities are negotiated through embodied, relational, performances within tourist spaces and through tourist practice. Both the stag tourism industry and the stag tourists themselves invest heavily in constructing an image of Eastern European cities such as Krakow based on gendered and sexualised assumptions, not to mention national cultural stereotypes. Further, throughout the stag tour weekend, active efforts are made by various actors, and most certainly not just the stag tourists themselves, to achieve and sustain a sense of collective masculinity through the 
gendered performance of tourist practice. Ultimately, what the men who participate in Eastern European stag tours are buying into is the idea that a time and place where masculinity can be performed and acted out, to a large extent, unproblematically can be packed as tourist experience.

\section{References}

Benwell, B. (2003) Masculinity and Men’s Lifestyle Magazines. Oxford: Blackwell.

Benwell, B. (2004) ‘Ironic discourse: Evasive masculinity in men’s lifestyle magazines’, Men and Masculinity, 73(1): 3-21.

Blackshaw, T. (2003) Leisure Life: Myth, Masculinity and Modernity. London: Routledge.

Campbell, H. (2000) ‘The glass phallus: Pub(lic) masculinity and drinking in rural New Zealand', Rural Sociology, 65(4): 562-81.

Channel 4 News (2007) ‘Stag parties plaguing Eastern Europe’, 20 September 2007.

Cohen, E. (1982) 'Thai girls and Farang men: The edge of ambiguity’, Annals of Tourism Research, 9(3): 403-28.

Coles, T. (2010) 'Negotiating the field of masculinity: The production and reproduction of multiples dominant masculinities’, Men and Masculinities, 12(1): 30-44.

Connell, R. (1987) Gender and Power: Society, the Person and Sexual Politics. Cambridge: Polity Press/Blackwell.

Connell, R. W. (1995) Masculinities. Cambridge: Polity.

Connell, R. and Messerschmidt, J. W. (2005) 'Hegemonic masculinity: Rethinking the concept', Gender and Society, 19(6): 829-59.

Donlon, J. and Agrusa, J. (2003) ‘Attractions of the naughty-gentlemen’s clubs as a tourism resource: The French quarter example', in T. Bauer and B. Mc Kercher (eds.) Sex and 
Tourism: Journeys of Romance, Love, and Lust. New York: Haworth Hospitality Press, pp. 119-36.

Edensor, T. and Kothari, U. (1994) 'The masculinisation of Stirling's heritage’ in V. Kinnaird and D. Hall (eds.) Tourism: A Gender Analysis. Chichester: Wiley, pp. 164-87.

Enloe, C. (1989) Bananas, Beaches and Bases: Making Feminist Sense of International Politics. London: Pandora.

Foreign and Commonwealth Office (2005) 'British Hens and Stags: In trouble Abroad', 30 August 2005.

Frohlick, S. (2010) 'The sex of tourism? Bodies under suspicion in paradise’ in J. Scott and T. Selwyn (eds.) Thinking Through Tourism. Oxford: Berg, pp. 51-70.

Frohlick, S. (2013) 'Intimate tourism markets: Money, gender, and the complexity of erotic exchange in a Costa Rican Caribbean town', Anthropological Quarterly, 86(1): 133-62.

Hesse, M. and Tutenges, S. (2011) 'Young tourists visiting strip clubs and paying for sex', Tourism Management, 32(4): 869-74.

Hobbs, J., Na Pattalung, P. and Chandler, R. (2011) 'Advertising Phuket’s nightlife on the Internet: A case study of double binds and hegemonic masculinity in sex tourism', Journal of Social Issues in Southeast Asia, 26(1): 80-104.

Jefferson, T. (2002) 'Subordinating hegemonic masculinity’, Theoretical Criminology, 6(1): 63-88.

Katsulis, Y. (2010) ““Living like a King”: Conspicuous consumption, virtual communities, and the social construction of paid sexual encounters by U.S. sex tourists', Men and Masculinities, 13(2): 210-30.

Kinnaird, V. and Hall, D. (1994) Tourism: A Gender Analysis. Chichester: Wiley.

Korobov, N. (2005). 'Ironizing masculinity: How adolescent boys negotiate heteronormative dilemmas in conversational interaction', Journal of Men’s Studies, 13(2): 225-46. 
Korobov, N. (2009) ‘Expanding hegemonic masculinity: The use of irony in young men’s stories about romantic experiences', American Journal of Men's Health, 3(4): 286-99.

Laing, J. and Crouch, G. (2011) 'Frontier tourism: Retracing mythical journeys', Annals of Tourism Research, 38(4): 1516-34.

Malam, L. (2004) 'Performing masculinity on the Thai Beach scene', Tourism Geographies, 6(4): 455-71.

Nayak, A. (2003) 'Last of the 'real Geordies': White masculinities and the subcultural response to deindustrialisation', Environment and Planning D: Society and Space, 21(1): 7-25.

Noy, C. (2007). 'Travelling for masculinity: The construction of bodies/spaces in Israeli backpackers’ narratives’ in A. Pritchard, N. Morgan, I. Ateljevic and C. Harris (eds.) Tourism and Gender: Embodiment, Sensuality and Experience. Wallingford: CABI, pp. 47-72.

Poonan, N. (2012) 'Stag holiday soldier drowns in lake’, The Sun, 28 June 2012.

Pritchard, A. and Morgan, N. J. (2000) 'Privileging the male gaze: Gendered tourism landscapes', Annals of Tourism Research, 27(4): 884-905.

Pritchard, A., Morgan, N., Ateljevic, I. and Harris, C. (eds.) (2007) Tourism and Gender: Embodiment, Sensuality and Experience: Embodiment, Sensuality and Experience. Wallingford: CAB International.

Sanchez Taylor, J. (2001) 'Dollars are a girl's best friend? Female tourists’ sexual behaviour in the Caribbean', Sociology, 35(3): 749-64.

Sherman, J. (2006) 'Stag night revellers 'should pay for embassy crisis help', The Times Online, 20 April 2006.

Sinclair, T. (1997) Gender, Work and Tourism. London: Routledge.

Spracklen, K. (2013) Leisure, Sports and Society. Basingstoke: Palgrave Macmillan 
Swain, M. B. (1995) 'Gender in tourism’, Annals of Tourism Research, 22(2): 247-66.

Thurnell-Read, T. (2012) 'What happens on tour: The premarital stag tour, homosocial bonding and male friendship', Men and Masculinities. 15(3): 249-70.

Thurnell-Read, T. (2011a) “Common-sense’ research: Senses, emotions and embodiment in researching stag tourism in Eastern Europe', Methodological Innovations Online, 6(3): 39-49.

Thurnell-Read, T. (2011b) 'Tourism place and space: British stag tourism in Poland', Annals of Tourism Research, 39(2): 801-19.

Thurnell-Read, T. (2011c) ““Off the leash and out of control”: Masculinities and embodiment in Eastern European stag tourism', Sociology, 45(6): 977-91.

Tutenges, S. (2012) 'Nightlife tourism: A mixed methods study of young tourists at an international nightlife resort', Tourist Studies, 12(2): 131-50.

Urry, J. (1990/2002) The Tourist Gaze: Leisure and Travel in Contemporary Societies. London: Sage.

Whelehan, I. (2000) Overloaded: Popular Culture and the Future of Feminism. London: Women’s Press. 